\title{
Subtype of breast cancer influences sentinel lymph node positivity
}

\author{
Piotr Kędzierawski ${ }^{1,2}$, Artur Bocian ${ }^{3}$, Agnieszka Radowicz-Chil' ${ }^{2,4}$, Anna Huruk-Kuchinka \\ Ryszard Mężyk ${ }^{5}$
}

\begin{abstract}
Submitted: 27 February 2020
Accepted: 23 September 2020

Arch Med Sci

DOI: https://doi.org/10.5114/aoms.2019.88595

Copyright (c) 2020 Termedia \& Banach
\end{abstract}

${ }^{1}$ Department of Radiotherapy, Holycross Cancer Centre, Kielce, Poland

${ }^{2}$ The Faculty of Medicine and Health Sciences, Jan Kochanowski University, Kielce, Poland ${ }^{3}$ Department of Surgery, Holycross Cancer Centre, Kielce, Poland

${ }^{4}$ Department of Pathology, Holycross Cancer Centre, Kielce, Poland

${ }^{5}$ Department of Epidemiology, Holycross Cancer Centre, Kielce, Poland

\begin{abstract}
Introduction: The purpose of the study was to determine the correlation between biological subtype of breast cancer and the risk of its metastasis to a sentinel lymph node.

Material and methods: In the analysed group there were 1018 women with breast cancer, clinically node negative, untreated previously. Luminal A subtype was recognised in $57 \%$ of patients. A positive sentinel lymph node was detected in $26.5 \%$ of women.

Results: In the multivariate analysis only age and tumour size proved to be significant for the entire group, respectively: $O R=0.59, p=0.0004$; $\mathrm{OR}=1.96 ; p<0.0001$. For Luminal $\mathrm{A}$ subtype values were $\mathrm{OR}=0.51$, $p=0.0007 ; \mathrm{OR}=1.78, p=0.0045$, respectively. For Luminal B patients, in women over 61 years, the risk of sentinel node metastasis probability decreases by $67 \%$ and for tumours over $21 \mathrm{~mm}$ the probability of positive sentinel node metastasis increases by $117 \%$.

Conclusions: According to our analysis luminal breast cancers are most numerous subtypes, and in these cases we expect more frequent instances of metastasis to a sentinel node. Following the most updated and modern procedures of breast cancer patients' treatment a procedure of sentinel lymph node biopsy is used, replacing an aggressive treatment in the axilla region. In regards to our analysis we should be more vigilant in estimation of regional lymph nodes in luminal patients under sixty with high grade tumours and the tumour diameter more than $20 \mathrm{~mm}$.
\end{abstract}

Key words: breast cancer, sentinel lymph node biopsy, biological subtype.

\section{Introduction}

The status of lymph nodes is an independent prognostic factor in women with breast cancer [1, 2]. A sentinel node biopsy procedure is now considered as the standard of care for patients with early-stage breast cancer. In the Holycross Cancer Centre in Kielce, Poland the sentinel lymph node biopsy (SLNB) has been performed since 2007 [3].

Recently the treatment of cancer patients, particularly those with breast cancer, has become more patient-oriented and is strictly connected with the biological subtype of cancer [4-6]. But in clinically node-neg-
Corresponding author:

Piotr Kędzierawski PhD Department of Radiotherapy Holycross Cancer Centre 3 Artwińskiego St 25-734 Kielce, Poland E-mail:

piotrkedzierawski@wp.pl 
Table I. Characteristics of the entire group of patients

\begin{tabular}{|c|c|}
\hline Factor & Number \\
\hline$N$ & 1018 \\
\hline \multicolumn{2}{|l|}{ Age } \\
\hline Mean (SD) & $60(11)$ \\
\hline Median $\left(\mathrm{Q}_{1}-\mathrm{Q}_{2}\right)$ & $61(52-67)$ \\
\hline Min-max & $28-92$ \\
\hline \multicolumn{2}{|l|}{ Age [years] } \\
\hline$\leq 61$ & $690(67.8 \%)$ \\
\hline$>61$ & $328(32.2 \%)$ \\
\hline \multicolumn{2}{|l|}{ Side } \\
\hline Left & $518(50.9 \%)$ \\
\hline Right & $500(49.1 \%)$ \\
\hline \multicolumn{2}{|l|}{ Type of cancer } \\
\hline No specific type & $870(85.5 \%)$ \\
\hline Lobular cancer & $98(9.6 \%)$ \\
\hline Other* & $50(4.9 \%)$ \\
\hline \multicolumn{2}{|l|}{ Grade } \\
\hline 1 & $550(54.1 \%)$ \\
\hline 2 & $382(37.6 \%)$ \\
\hline 3 & $85(8.4 \%)$ \\
\hline \multicolumn{2}{|l|}{ Tumour size } \\
\hline Mean (SD) & $20.6(10.8)$ \\
\hline Median $\left(\mathrm{Q}_{1}-\mathrm{Q}_{2}\right)$ & $20(13-26)$ \\
\hline Min-max & $1-80$ \\
\hline \multicolumn{2}{|l|}{ Tumour size [mm] } \\
\hline$\leq 21$ & $429(41.1 \%)$ \\
\hline$>21$ & $589(57.9 \%)$ \\
\hline \multicolumn{2}{|l|}{ pT } \\
\hline 1 & $572(56.2 \%)$ \\
\hline 2 & $432(42.4 \%)$ \\
\hline 3 & $13(1.3 \%)$ \\
\hline 4 & $1(0.1 \%)$ \\
\hline \multicolumn{2}{|l|}{ Sentinel node status } \\
\hline $\mathrm{N}$ negative & $748(73.5 \%)$ \\
\hline $\mathrm{N}$ positive & $270(26.5 \%)$ \\
\hline \multicolumn{2}{|l|}{ Biological subtype } \\
\hline Luminal A & $582(57.2 \%)$ \\
\hline Luminal B & $160(15.7 \%)$ \\
\hline $\begin{array}{l}\text { Luminal B progesterone negative } \\
\text { receptor }\end{array}$ & $102(10.0 \%)$ \\
\hline Luminal B HER2 positive & $77(7.6 \%)$ \\
\hline Triple negative & $74(7.3 \%)$ \\
\hline Non luminal & $23(2.3 \%)$ \\
\hline
\end{tabular}

ative patients positive sentinel nodes are found and a decision about management in the axilla region is difficult, particularly in patients after a subcutaneous mastectomy and with a positive sentinel lymph node. Statistically in the majority of patients the Luminal A subtype is determined and the upfront therapy for these patients is surgery. Thus for positive sentinel node patients a proper strategy of treatment should be established.

The purpose of the study was to determine the correlation between biological subtype of breast cancer and the risk of its metastasis to a sentinel lymph node (SLN). The factors known prior to surgical treatment, namely age, tumour diameter, grade, type of cancer, and biological subtype, were evaluated.

\section{Material and methods}

In the analysed group there were 1018 consecutive patients with breast cancer, clinically node negative, untreated previously, in whom a sentinel lymph node biopsy procedure was performed. In 802 women a breast-conserving treatment, in 149 subcutaneous mastectomy and in 67 patients simple mastectomy were performed. All the patients were diagnosed and treated in the Holycross Cancer Centre.

\section{Statistical analysis}

Categorical variables were described with absolute frequencies and percentages and a $\chi^{2}$ test was used to compare categorical characteristics. Continuous variables were described by mean and standard deviations, the median and quartiles, as well as by minimum and maximum values. The normality of the distribution of the studied features was tested using the Shapiro-Wilk test. For features with normal distribution the $t$-test (for 2 groups) and the ANOVA test (for more than two groups) were used, for non-normal features the non-parametric tests of Mann-Whitney (for 2 groups) and Kruskal-Wallis (for more than two groups) were used. A receiver operating characteristic (ROC) curve analysis was applied. Sensitivity and specificity, positive and negative predictive values and confidence intervals were determined. The comparison of ROC curves was made. To identify the predictors of potential metastasis to the lymph nodes, univariate and multivariate logistic regression analyses were performed. A $p$-value $<0.05$ was considered statistically significant. All statistical analysis was performed with the MedCalc Statistical Software version 18.10.2 (MedCalc Software bvba, Ostend, Belgium; http:// www.medcalc.org; 2018). 


\section{Results}

The median age was sixty-one. In $85 \%$ of cases an invasive carcinoma of no special type (NST) was diagnosed. In approximately $56 \%$ of cases the diameter of the tumour was no more than $20 \mathrm{~mm}$. Luminal A subtype was recognised in $57 \%$ of patients. A positive sentinel lymph node was detected in $26.5 \%$ of women (Table I). The average number of removed sentinel nodes was 2.3 (median: 2 , range $1-14)$. the average number of positive sentinel nodes was 1.4 (median: 1, range 1-8). The biological subtype was not a statistically significant factor in correlation with the probability of metastasis to a sentinel node $(p=0.4028)$ (Table II). Age was not statistically significant in relation to the entire group, as well as for patients

Table II. Relationship between sentinel node status and biological subtype

\begin{tabular}{|lccc|}
\hline Biological subtype & SLN negative & SLN positive & Total \\
\hline Luminal A & $426(73.2 \%)$ & $156(26.8 \%)$ & $582(57.2 \%)$ \\
\hline Luminal B & $110(68.7 \%)$ & $50(31.2 \%)$ & $160(15.7 \%)$ \\
\hline Luminal B progesterone negative O & $81(79.4 \%)$ & $21(20.6 \%)$ & $102(10.0 \%)$ \\
\hline Luminal B HER2 positive & $59(76.6 \%)$ & $18(23.4 \%)$ & $77(7.6 \%)$ \\
\hline Triple negative & $55(74.3 \%)$ & $4(17.4 \%)$ & $23(2.3 \%)$ \\
\hline Non-luminal & $19(82.6 \%)$ & $268(26.3 \%)$ & $1018(100 \%)$ \\
\hline Total & $750(73.7 \%)$ & & $74)$ \\
\hline -value & 0.4028 & & $2 \%(9.7 \%)$ \\
\hline
\end{tabular}

Table III. Relationship between age and biological subtype and sentinel node status

\begin{tabular}{|c|c|c|c|c|}
\hline \multirow[t]{2}{*}{ Biological subtype } & \multirow{2}{*}{$\begin{array}{c}\text { Age (years) } \\
\text { Number } \\
\text { Min-max. } \\
\text { Mean (SD) } \\
\text { Median }\left(Q_{1}-Q_{3}\right)\end{array}$} & \multicolumn{2}{|c|}{ Sentinel node status } & \multirow[t]{2}{*}{$P$-value } \\
\hline & & SLN negative & SLN positive & \\
\hline Luminal A & $\begin{array}{c}n=582 \\
31-92 \\
60.5(10.9) \\
62(52-68)\end{array}$ & $\begin{array}{c}n=426 \\
34-89 \\
61.5(10.5) \\
63(55-68)\end{array}$ & $\begin{array}{c}n=156 \\
31-92 \\
57.8(11.7) \\
57(50-66)\end{array}$ & $0.0001^{\mathrm{MW}}$ \\
\hline Luminal B & $\begin{array}{c}n=160 \\
32-79 \\
58.3(11.1) \\
60(50-66)\end{array}$ & $\begin{array}{c}n=110 \\
34-79 \\
59.5(10.1) \\
62(54-67)\end{array}$ & $\begin{array}{c}n=50 \\
32-78 \\
55.4(12.6) \\
54.5(44-64)\end{array}$ & $0.0248^{\mathrm{MW}}$ \\
\hline $\begin{array}{l}\text { Luminal B progesterone negative } \\
\text { receptor }\end{array}$ & $\begin{array}{c}n=102 \\
30-80 \\
61.4(9.6) \\
63(57-68)\end{array}$ & $\begin{array}{c}n=81 \\
30-77 \\
60.6(9.3) \\
62(57-68)\end{array}$ & $\begin{array}{c}n=21 \\
41-80 \\
64.3(10.2) \\
68(57-71)\end{array}$ & $0.1204^{\mathrm{mw}}$ \\
\hline Luminal B HER2 positive & $\begin{array}{c}n=77 \\
33-82 \\
59.1(10.9) \\
60(57-68)\end{array}$ & $\begin{array}{c}n=59 \\
33-79 \\
59.1(11.0) \\
60(53-67)\end{array}$ & $\begin{array}{c}n=18 \\
39-82 \\
59(10.9) \\
61(53-64)\end{array}$ & $0.9772^{\top}$ \\
\hline Triple negative & $\begin{array}{c}n=74 \\
28-81 \\
58.6(11.1) \\
60(53-66)\end{array}$ & $\begin{array}{c}n=55 \\
38-81 \\
59.5(10.0) \\
60(54-66)\end{array}$ & $\begin{array}{c}n=19 \\
28-77 \\
55.9(13.5) \\
56(47-66)\end{array}$ & $0.2237^{\top}$ \\
\hline Non-luminal & $\begin{array}{c}n=23 \\
37-76 \\
56.3(11.2) \\
59(48-64)\end{array}$ & $\begin{array}{c}n=19 \\
37-76 \\
55.8(11.5) \\
57(48-64)\end{array}$ & $\begin{array}{c}n=4 \\
42-67 \\
58.5(11.2) \\
63(52-65)\end{array}$ & $0.6713^{\top}$ \\
\hline$P$-value & & $\begin{array}{c}0.0697^{\mathrm{KW}} \\
0.1290^{\mathrm{KW}} \\
0.1130^{\mathrm{ANOVA}}\end{array}$ & & - \\
\hline
\end{tabular}

P-value for: MW - Mann-Whitney test (independent samples), T-independent samples t-test, KW - Kruskal-Wallis test, ANOVA - one-way analysis of variance. 
Table IV. Relationship between tumour size and biological subtype and sentinel node status

\begin{tabular}{|c|c|c|c|c|}
\hline \multirow[t]{2}{*}{ Biological subtype } & \multirow{2}{*}{$\begin{array}{c}\text { Tumour size }(\mathrm{mm}) \\
\text { Number } \\
\text { Min-max. } \\
\text { Mean (SD) } \\
\text { Median }\left(\mathrm{Q}_{1}-\mathrm{Q}_{3}\right)\end{array}$} & \multicolumn{2}{|c|}{ Sentinel node status } & \multirow[t]{2}{*}{$P$-value } \\
\hline & & SLN negative & SLN positive & \\
\hline Luminal A & $\begin{array}{c}n=582 \\
1-60 \\
19.5(9.4) \\
19(13-25)\end{array}$ & $\begin{array}{c}n=426 \\
1-55 \\
18.0(8.8) \\
17(12-24)\end{array}$ & $\begin{array}{c}n=156 \\
2-60 \\
23.7(9.6) \\
23(17-30)\end{array}$ & $<0.0001^{\mathrm{MW}}$ \\
\hline Luminal B & $\begin{array}{c}n=160 \\
2-80 \\
24.3(18.9) \\
22(15-30)\end{array}$ & $\begin{array}{c}n=110 \\
2-50 \\
21.2(11.0) \\
20(15-30)\end{array}$ & $\begin{array}{c}n=50 \\
12-80 \\
30.4(14.6) \\
29(22-33)\end{array}$ & $0.0003^{\mathrm{MW}}$ \\
\hline $\begin{array}{l}\text { Luminal B progesterone negative } \\
\text { receptor }\end{array}$ & $\begin{array}{c}n=102 \\
1-75 \\
19.9(13.3) \\
16(11-27)\end{array}$ & $\begin{array}{c}n=81 \\
1-60 \\
17.4(11.3) \\
15(10-25)\end{array}$ & $\begin{array}{c}n=21 \\
11-75 \\
29.5(15.9) \\
22(20-39)\end{array}$ & $0.0002^{\mathrm{MW}}$ \\
\hline Luminal B HER2 positive & $\begin{array}{c}n=77 \\
3-50 \\
19.9(10.1) \\
19(12-25)\end{array}$ & $\begin{array}{c}n=59 \\
3-50 \\
17.9(9.3) \\
18(11-23)\end{array}$ & $\begin{array}{c}n=18 \\
10-43 \\
26.5(9.9) \\
27(22-35)\end{array}$ & $0.0011^{\mathrm{mw}}$ \\
\hline Triple negative & $\begin{array}{c}n=74 \\
1-60 \\
22.6(10.9) \\
22(15-28)\end{array}$ & $\begin{array}{c}n=55 \\
1-60 \\
22.2(11.7) \\
20(15-30)\end{array}$ & $\begin{array}{c}n=19 \\
8-42 \\
23.7(8.1) \\
25(19-27)\end{array}$ & $0.5953^{\top}$ \\
\hline Non-luminal & $\begin{array}{c}n=23 \\
2-55 \\
20.0(13.5) \\
19(7-29)\end{array}$ & $\begin{array}{c}n=19 \\
2-55 \\
21.1(13.8) \\
20(9-29)\end{array}$ & $\begin{array}{c}n=4 \\
5-33 \\
15.0(12.8) \\
11(6-24)\end{array}$ & $0.4248^{\top}$ \\
\hline$P$-value & $<0.0001^{\mathrm{KW}}$ & $0.0019^{\mathrm{kW}}$ & $0.0163^{\mathrm{KW}}$ & - \\
\hline
\end{tabular}

P-value for: MW - Mann-Whitney test (independent samples), T-independent samples t-test, KW - Kruskal-Wallis test, ANOVA - one-way analysis of variance.

Table V. Relationship between tumour grade and biological subtype

\begin{tabular}{|c|c|c|c|c|}
\hline \multirow[t]{2}{*}{ Biological subtype } & \multicolumn{3}{|c|}{ Tumour grade } & \multirow[t]{2}{*}{ Total } \\
\hline & 1 & 2 & 3 & \\
\hline Luminal A & $410(70.4 \%)$ & $164(28.2 \%)$ & $8(1.4 \%)$ & $582(57.2 \%)$ \\
\hline Luminal B & $41(25.6 \%)$ & $98(61.2 \%)$ & $21(13.1 \%)$ & $160(15.7 \%)$ \\
\hline Luminal B progesterone negative receptor & $63(61.8 \%)$ & $33(32.4 \%)$ & $6(5.9 \%)$ & $102(10.0 \%)$ \\
\hline Luminal B HER2 positive & $25(32.5 \%)$ & $44(57.1 \%)$ & $8(10.4 \%)$ & $77(7.6 \%)$ \\
\hline Triple negative & $9(12.2 \%)$ & $32(43.2 \%)$ & $33(44.6 \%)$ & $74(7.3 \%)$ \\
\hline Non-luminal & $3(13.0 \%)$ & $11(47.8 \%)$ & $9(39.1 \%)$ & $23(2.3 \%)$ \\
\hline Total & $551(54.1 \%)$ & $382(37.5 \%)$ & $85(8.3 \%)$ & 1018 \\
\hline$P$-value & & & & \\
\hline
\end{tabular}

with or without metastases to the sentinel node $(p=0.0697)$. However, patients with Luminal A and positive SLN were younger; the median age was 57 years vs 63 years for Luminal A negative SLN $(p=0.0001)$. In Luminal B patients with SLN metastasis the age was 6.5 years lower than in the SLN negative ones $(p=0.0248)$ (Table III). Tumour size was statistically significant in relation to biological subtype and sentinel node status. In triple negative and non-luminal subtypes this correlation was not found $(p=0.5953$ and $p=0.4248$ respectively) (Table IV). A statistically significant association was found for biological subtype and tumour grade $(p<0.0001)$ (Table V). A receiver operating characteristic analysis was performed for sentinel node negative and positive status and for 
independent variables: age, grade and tumour size. Outcomes are shown in Figure 1. Sensitivity, specificity, +PV (positive predictive value), -PV (negative predictive value) for age were respectively: $44.8 \%$, $72.3 \%, 36.6 \%$, 78.6\%; for grade respectively: $51.5 \%$, $56.1 \%, 29.6 \%, 75.8 \%$; and for tumour size respectively: $61.9 \%, 66.1 \%, 39.5 \%, 82.9 \%$. Analysed features show the greatest sensitivity and specificity for tumour size. At the same time, all of them have high -PV. All of them are statistically significant. The biggest area under the curve (AUC) was estimated for tumour size and it is statistically significantly different from AUC for age ( $p=0.0005)$ and tumour grade $(p<0.0001)$. A significant difference for AUC for age and tumour grade was not found ( $p=0.1584$ ) (Figure 1$)$. Table VI shows outcomes of the univariate analysis for biological subtypes and for the entire group. The following proved to be statistically significant: for Luminal A, age $(p=0.0001)$, tumour size $(p=0.0007)$, tumour grade $(p=0.0259)$ and type of cancer $(p=0.0326)$; for Luminal $\mathrm{B}$, age $(p=0.0039)$ and tumour size ( $p=0.0284)$; for Luminal B HER2 positive, tumour size only ( $p=0.0162)$; for the entire group, age $(p=0.0001)$, tumour size $(p<0.0001)$, and tumour grade $(p=0.0228)$. For factors which were statistically significant in the univariate analysis, multivariate analysis was performed. Among them only age and tumour size proved to be significant for the entire group, respectively: $\mathrm{OR}=0.59, p=0.0004 ; \mathrm{OR}=1.96 ; p<0.0001$; for the Luminal A subtype, $\mathrm{OR}=0.51, p=0.0007$; $\mathrm{OR}=1.78, p=0.0045$, respectively. For Luminal $\mathrm{B}$ patients, in women over 61 years, the risk of sentinel node metastasis probability decreases by $67 \%$ and for tumours over $21 \mathrm{~mm}$ the probability of a positive sentinel node metastasis increases by $117 \%$ (Table VII).

\section{Discussion}

Luminal A tumours are the most common breast cancers. Other biological subtypes are less numerous [7-10]. Additionally in our series, Luminal B cancer subtype with negative expression of a progesterone receptor was detected, which is associated with different biology and prognosis in this particular subtype [11-13]. A sentinel lymph node biopsy can be performed in every patient with any biological subtype of breast cancer, even in triple negative and epidermal growth factor receptor 2 (HER2) positive patients in whom the strategy of treatment has recently changed [14-16, 18]. Systemic and antiHER2 therapy is applied in these patients at the beginning of the therapy, excluding patients in whom the tumour diameter is less than $10 \mathrm{~mm}$. Even in early stage disease we decide on neoadjuvant chemoand antiHER2 therapy. In many cases regression is

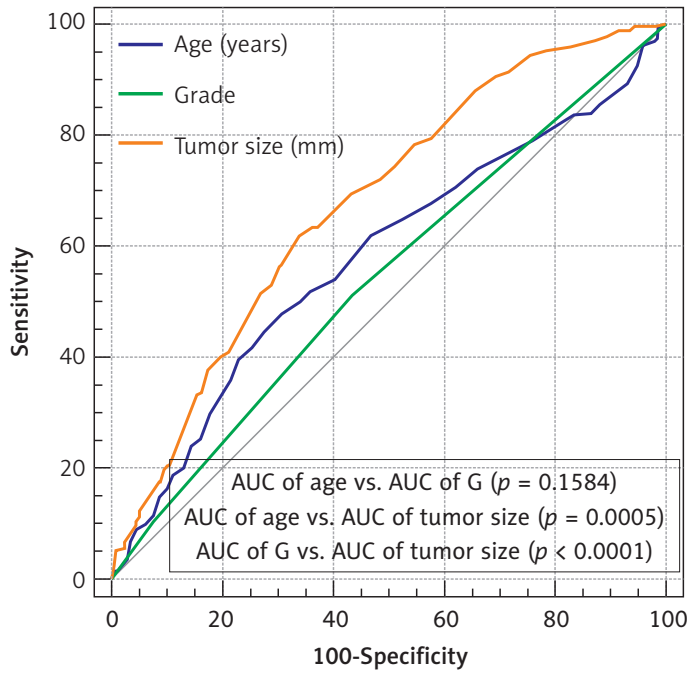

Figure 1. ROC comparison

achieved and non-harmful axillary surgery is used, replaced by a sentinel node biopsy procedure.

The available published data indicate that the risk of regional lymph node metastasis in triple negative breast cancer patients is low and an SLNB procedure may be not necessary [17-19]. However, still, for the aforementioned patients, even after a neoadjuvant systemic therapy, an SLNB procedure should be performed. In $40 \%$ of triple negative and HER2 positive cancers pathological complete regression has been achieved (own data, not published); thus this particular form of treatment should be applied.

Carcinogenesis of breast cancer is different in older women, and its development can last years, in contrast to young women. The most common subtype is Luminal A. Luminal A breast cancers are usually of low histological grade, with slow growth and a good prognosis, but quite frequently in young women the illness is more advanced at the time of making a diagnosis [20, 21].

Statistically, in the analysed group, the probability of sentinel lymph node metastasis did not differ between particular subtypes of cancers. For Luminal A and Luminal B cancers the following factors were proven to be statistically significant in relation to the risk of SLN metastasis: age, grade and tumour size, which is consistent with data reported in the literature [4, 10, 17, 22, 23]. Other authors point to different factors influencing the presence of metastasis in sentinel nodes. Majid et al. found that the presence of tumours measuring $>20 \mathrm{~mm}$, multifocality and lymphovascular invasion are strong predictive factors for SLN metastases [24]. According to a study by Ding et al. involving 417 patients, a univariate analysis revealed age, tumour size, histological grade and $\mathrm{Ki}-67$ index to be associated with SLN metastases, while Ki-67 index was not found to be significant 
Table VI. Univariate analysis of risk factors of sentinel lymph node metastasis

\begin{tabular}{|c|c|c|c|c|c|c|}
\hline Biological subtype & Measure & $\begin{array}{c}\text { Age } \\
<61 \text { vs. } \geq 61\end{array}$ & Side & $\begin{array}{l}\text { Tumour size } \\
<21 \text { vs. } \geq 21\end{array}$ & Grade: $1,2,3$ & $\begin{array}{c}\text { Lobular cancer } \\
\text { vs. } \\
\text { no special type }\end{array}$ \\
\hline Luminal A & $\begin{array}{c}p \text {-value } \\
\text { OR } \\
95 \% \mathrm{Cl}\end{array}$ & $\begin{array}{c}0.0001 \\
0.46 \\
0.32-0.67\end{array}$ & $\begin{array}{c}0.3635 \\
0.84 \\
0.58-1.22\end{array}$ & $\begin{array}{c}0.0007 \\
1.93 \\
1.32-2.81\end{array}$ & $\begin{array}{c}0.0259 \\
1.51 \\
1.05-2.16\end{array}$ & $\begin{array}{c}0.0326 \\
0.53 \\
0.30-0.95\end{array}$ \\
\hline Luminal B & $\begin{array}{c}p \text {-value } \\
\text { OR } \\
95 \% \mathrm{Cl}\end{array}$ & $\begin{array}{c}0.0039 \\
0.34 \\
0.16-0.71\end{array}$ & $\begin{array}{c}0.8639 \\
1.06 \\
0.54-2.08\end{array}$ & $\begin{array}{c}0.0284 \\
2.50 \\
1.10-5.68\end{array}$ & $\begin{array}{c}0.5296 \\
1.19 \\
0.69-2.07\end{array}$ & $\begin{array}{c}0.5648 \\
1.48 \\
0.39-5.65\end{array}$ \\
\hline $\begin{array}{l}\text { Luminal B } \\
\text { progesterone } \\
\text { negative receptor }\end{array}$ & $\begin{array}{c}p \text {-value } \\
\text { OR } \\
95 \% \mathrm{Cl}\end{array}$ & $\begin{array}{c}0.1930 \\
1.95 \\
0.71-5.34 \\
\end{array}$ & $\begin{array}{c}0.4530 \\
1.45 \\
0.55-3.79\end{array}$ & $\begin{array}{c}0.3606 \\
1.60 \\
0.58-4.38 \\
\end{array}$ & $\begin{array}{c}0.4829 \\
1.32 \\
0.61-2.82 \\
\end{array}$ & $\begin{array}{c}0.8820 \\
1.20 \\
0.34-3.72 \\
\end{array}$ \\
\hline $\begin{array}{l}\text { Luminal B HER2 } \\
\text { positive }\end{array}$ & $\begin{array}{c}p \text {-value } \\
\text { OR } \\
95 \% \mathrm{Cl}\end{array}$ & $\begin{array}{c}0.5238 \\
0.71 \\
0.24-2.07\end{array}$ & $\begin{array}{c}0.7526 \\
1.19 \\
0.41-3.41 \\
\end{array}$ & $\begin{array}{c}0.0162 \\
6.75 \\
1.42-32.02 \\
\end{array}$ & $\begin{array}{c}0.9909 \\
0.99 \\
0.42-2.34\end{array}$ & $\begin{array}{c}0.8539 \\
1.24 \\
0.12-11.82 \\
\end{array}$ \\
\hline Triple negative & $\begin{array}{c}p \text {-value } \\
\text { OR } \\
95 \% \mathrm{Cl}\end{array}$ & $\begin{array}{c}0.4320 \\
0.65 \\
0.22-1.90\end{array}$ & $\begin{array}{c}0.5996 \\
1.33 \\
0.46-3.80\end{array}$ & $\begin{array}{c}0.3414 \\
1.82 \\
0.53-6.29\end{array}$ & $\begin{array}{c}0.2707 \\
1.58 \\
0.70-3.58\end{array}$ & $\begin{array}{c}0.7112 \\
1.53 \\
0.16-14.65 \\
\end{array}$ \\
\hline Non-luminal & $\begin{array}{c}p \text {-value } \\
\text { OR } \\
95 \% \mathrm{Cl}\end{array}$ & $\begin{array}{c}0.1897 \\
5.14 \\
0.45-59.46\end{array}$ & $\begin{array}{c}0.9981 \\
- \\
- \\
\end{array}$ & $\begin{array}{c}0.7727 \\
0.73 \\
0.08-6.31 \\
\end{array}$ & $\begin{array}{c}0.1397 \\
5.69 \\
0.57-57.32 \\
\end{array}$ & $\begin{array}{c}0.9985 \\
- \\
- \\
\end{array}$ \\
\hline Entire group & $\begin{array}{c}p \text {-value } \\
\text { OR } \\
95 \% \mathrm{Cl}\end{array}$ & $\begin{array}{c}<0.0001 \\
0.54 \\
0.41-0.61\end{array}$ & $\begin{array}{c}0.7024 \\
0.95 \\
0.72-1.25\end{array}$ & $\begin{array}{c}<0.0001 \\
2.05 \\
1.52-2.76\end{array}$ & $\begin{array}{c}0.0228 \\
1.28 \\
1.04-1.58\end{array}$ & $\begin{array}{c}0.2841 \\
0.78 \\
0.50-1.23\end{array}$ \\
\hline
\end{tabular}

Table VII. Multivariate analysis of risk factors of sentinel node metastasis (ENTER method)

\begin{tabular}{|lccccc|}
\hline Biological subtype & Measure & $\begin{array}{c}\text { Age } \\
<61 \text { vs. } \geq 61\end{array}$ & $\begin{array}{c}\text { Tumour size } \\
<21 \text { vs. } \geq 21\end{array}$ & $\begin{array}{c}\text { Grade } \\
1,2,3\end{array}$ & $\begin{array}{c}\text { Lobular cancer } \\
\text { vs. non specific }\end{array}$ \\
\hline Luminal A & $p$-value & 0.0007 & 0.0045 & 0.6068 & 0.0765 \\
& OR & 0.51 & 1.78 & 1.11 & 0.58 \\
& $95 \% \mathrm{Cl}$ & $0.35-0.75$ & $1.20-2.65$ & $0.76-1.62$ & $0.32-1.06$ \\
\hline Luminal B & $p$-value & 0.0060 & 0.0887 & 0.9333 & 0.7702 \\
& OR & 0.33 & 2.17 & 1.03 & 1.23 \\
& $95 \% \mathrm{Cl}$ & $0.15-0.73$ & $0.89-5.31$ & $0.57-1.86$ & $0.30-5.02$ \\
\hline Entire group & $p$-value & 0.0004 & $<0.0001$ & 0.7830 & 0.3121 \\
& OR & 0.59 & 1.96 & 1.03 & 0.79 \\
& $95 \% \mathrm{Cl}$ & $0.44-0.79$ & $1.43-2.68$ & $0.83-1.30$ & $0.50-1.25$ \\
\hline
\end{tabular}

in a multivariate analysis [10]. In a series of 324 patients, Mao found no association between Ki-67 index and SLN status lower or higher than 14. A Ki-67 index $>14$ percent has been reported to be associated with SLN metastases [25-28]. Other investigators indicate a relationship between tumour-infiltrating lymphocytes (TILs) and higher probability of regional lymph nodes metastases. Macchetti et al. discovered a statistically significant correlation between CD4-positive TILs and axillary lymph node involvement, but did not find a correlation between CD8-positive TILS and axillary lymph node involvement [29]. Conversely, Matkowski et al. found a highly significant correlation between both CD4-positive and CD8-positive TILs and axillary lymph node involvement [30]. According to our own data a precise radiological evaluation should be performed in women under sixty and in highly malignant tumours of over $20 \mathrm{~mm}$ in diameter. A very thorough diagnostic work-up should be performed not only in relation to a primary tumour but also to regional lymph nodes. A further strategy after surgery for Luminal A cancer patients is connected with the number of positive sentinel lymph nodes. Even a macrometastasis to a sentinel node in Luminal A cancer patients is not an indication for axillary lymphadenectomy, which can be replaced by a radiotherapy of regional lymph nodes. In sentinel node positive patients, no additional metastases are found in the remaining lymph nodes removed on axillary lymphadenectomy in about $50-60 \%$ of patients [31]. Subsequently in several countries axillary radiotherapy is approved in lieu of axillary lymphadenectomy [32-34]. Supplementary chemotherapy can be applied in the case of numerous positive sentinel lymph nodes. In the case of existence of metastases to one or two sentinel lymph 
nodes usually chemotherapy is not provided for these patients and hormone therapy is the treatment of choice regarding systemic treatment. Conversely, in Luminal B, Luminal B HER 2 positive, triple negative or non-luminal patients, chemotherapy and anti-HER2 therapy are used [18, 35].

\section{Conclusions}

According to our analysis, luminal breast cancers are the most numerous subtypes and in these cases we expect more frequent instances of metastasis to a sentinel node. Based on our outcomes we can state that the risk of a sentinel node metastasis decreases in women older than 61 years for Luminal A by $54 \%$, Luminal B by $64 \%$, and for the entire group by $46 \%$. A tumour size bigger than $21 \mathrm{~mm}$ increases the probability of a positive sentinel node for Luminal A and Luminal B by $93 \%$ and $150 \%$, respectively. The increase of the tumour grade causes the higher probability of a sentinel node metastasis, for Luminal A by $50 \%$, for the entire group by $28 \%$. Following the most upto-date and modern procedures of breast cancer patients' treatment, a procedure of a sentinel lymph node biopsy is used, replacing an aggressive treatment in the axilla region.

\section{Conflicts of interest}

The authors declare no conflict of interest.

\section{References}

1. Yoshihara E, Smeets A, Laenen A, et al. Predictors of axillary lymph node metastases in early breast cancer and their applicability in clinical practice. Breast 2013; 22: 357-61.

2. Holm-Rasmussen EV, Jensen MB, Balslev E, et al. Reduced risk of axillary lymphatic spread in triple-negative breast cancer. Breast Cancer Res Treat 2015; 149: 229-36.

3. Kędzierawski P, Bocian A, Ciepiela I, Kołacińska A, Macek P, Góźdź S Treatment outcomes of 213 breast cancer patients after sentinel node biopsy-single center experience. Arch Med Sci Civil Dis 2017; 2: e130-e4.

4. He ZY, Wu SG, Yang Q, et al. Breast cancer subtype is associated with axillary lymph node metastasis: a retrospective cohort study. Medicine (Baltimore) 2015; 94: e2213.

5. Mattes MD, Bhatia JK, Metzger D, Ashamalla H, Katsoulakis E. Breast cancer subtype as a predictor of lymph node metastasis according to the SEER registry. J Breast Cancer 2015; 18: 143-8.

6. Jones T, Neboori H, Wu H, et al. Are breast cancer subtypes prognostic for nodal involvement and associated with clinicopathologic features at presentation in early-stage breast cancer? Ann Surg Oncol 2013; 20: 2866-72.

7. Voduc KD, Cheang MC, Tyldesley S, Gelmon K, Nielsen TO, Kennecke $\mathrm{H}$. Breast cancer subtypes and the risk of local and regional relapse. J Clin Oncol 2010; 28: 1684-91.

8. Ribelles N, Perez Villa L, Jerez JM, et al. Pattern of recurrence of early breast cancer is different according to intrinsic subtype and proliferation index. Breast Cancer Res 2013; 15: R98.
9. La Verde N, Biagioli E, Gerardi C, et al. Role of patient and tumor characteristics on sentinel lymph node metastasis in patients with luminal early breast cancer: an observational study. Springerplus 2016; 5: 114.

10. Ding J, Jiang L, Wu W. Predictive value of clinicopathological characteristics for sentinel lymph node metastasis in early breast cancer. Med Sci Monit 2017; 23: 4102-8.

11. Ades F, Zardavas D, Bozovic-Spasojevic I, et al. Luminal B breast cancer: molecular characterization, clinical management, and future perspectives. J Clin Oncol 2014; 32: 2794-803.

12. Chen S, Huang L, Chen CM, Shao ZM. Progesterone receptor loss identifies luminal-type local advanced breast cancer with poor survival in patients who fail to achieve a pathological complete response to neoadjuvant chemotherapy. Oncotarget 2015; 6: 18174-82.

13. Lobbezoo DJ, van Kampen RJ, Voogd AC, et al. Prognosis of metastatic breast cancer subtypes: the hormone receptor/HER2-positive subtype is associated with the most favorable outcome. Breast Cancer Res Treat 2013; 141: 507-14.

14. Vici P, Pizzuti L, Natoli C, et al. Triple positive breast cancer: a distinct subtype? Cancer Treat Rev 2015; 41: 69-76.

15. Baker JI, Muhsen S, Zabor EC, Stempel M, Gemignani ML. Does lymph node status prior to neoadjuvant chemotherapy influence the number of sentinel nodes removed? Ann Surg Oncol 2018; 26: 336-42.

16. Mamtani A, Barrio AV, King TA, et al. How often does neoadjuvant chemotherapy avoid axillary dissection in patients with histologically confirmed nodal metastases? Results of a prospective study. Ann Surg Oncol 2016; 23: 3467-74.

17. Gangi A, Mirocha J, Leong T, Giuliano AE Triple-negative breast cancer is not associated with increased likelihood of nodal metastases. Ann Surg Oncol 2014; 21: 4098-103.

18. Pilewskie M, Morrow M. Axillary nodal management following neoadjuvant chemotherapy: a review. JAMA Oncol 2017; 3: 549-55.

19. Huszno J, Kołosza Z, Tęcza K, Pamuła-Piłat J, Mazur M, Grzybowska E. Comparison between NOD2 gene mutation carriers (3020insC) and non-carriers in breast cancer patients: a clinicopathological and survival analysis. Arch Med Sci Civil Dis 2018; 3: e10-e15.

20. Liu Z, Sahli Z, Wang Y, Wolff AC, Cope LM, Umbricht CB. Young age at diagnosis is associated with worse prognosis in the Luminal A breast cancer subtype: a retrospective institutional cohort study. Breast Cancer Res Treat 2018; 172: 689-702.

21. Lian W, Fu F, Lin Y, et al. The impact of young age for prognosis by subtype in women with early breast cancer. SCI Rep 2017; 7: 11625.

22. Bevilacqua JL, Kattan MW, Fey JV, Cody HS 3rd, Borgen PI, Van Zee KJ. Doctor, what are my chances of having a positive sentinel node? A validated nomogram for risk estimation. J Clin Oncol 2007; 25: 3670-9.

23. Reyal F, Rouzier R, Depont-Hazelzet B, et al. The molecular subtype classification is a determinant of sentinel node positivity in early breast carcinoma. PLoS One 2011; 6: e20297.

24. Majid S, Rydén L, Manjer J. Predictive factors for sentinel node metastases in primary invasive breast cancer: a population-based cohort study of 2552 consecutive patients. World J Surg Oncol 2018; 16: 54.

25. Mao F, Yao R, Peng L, Zhao JL, Liang ZY, Sun Q. Predictive clinicopathological characteristics affecting sentinel 
lymph node metastasis in early breast cancer patients. Transl Cancer Res 2017; 6: 968-75.

26. Costa ON, Castro RB, Oliveira CV, et al. Predictive factors of axillary metastasis in patients with breast cancer and positive sentinel lymph node biopsy. Rev Col Bras Cir 2017; 44: 391-6.

27. Viale G, Zurrida S, Maiorano E, et al. Predicting the status of axillary sentinel lymph nodes in 4351 patients with invasive breast carcinoma treated in a single institution. Cancer 2005; 103: 492-500.

28. Inic Z, Zegarac M, Inic M, et al. Difference between Luminal A and Luminal B subtypes according to Ki-67, tumour size, and progesterone receptor negativity providing prognostic information. Clin Med Insights Oncol 2014; 8: 107-111.

29. Macchetti AH, Marana HRC, Silva JS, et al. Tumor-infiltrating CD4+ $\mathrm{T}$ lymphocytes in early breast cancer reflect lymph node involvement. Clinics 2006; 61: 203-8.

30. Matkowski R, Gisterek I, Halon A. The prognostic role of tumor-infiltrating CD4 and CD8 T lymphocytes in breast cancer. Anticancer Res 2009; 29: 2445-2452.

31. Degnim AC, Griffith KA, Sabel MS, et al. Clinicopathologic features of metastasis in nonsentinel lymph nodes of breast carcinoma patients. Cancer 2003; 98: 2307-15.

32. Donker M, Van Tienhoven G, Straver ME, et al. Radiotherapy or surgery of the axilla after a positive sentinel node in breast cancer( EORTC 10981-22023 AMAROS): a randomised, multicentre, open label, phase 3 non-inferiority trial. Lancet Oncol 2014; 15: 1303-10.

33. De Boniface J, Frisell J, Andersson Y, et al. Survival and axillary recurrence following sentinel node-positive breast cancer without completion axillary dissection: the randomized controlled SENOMAC trial. BMC Cancer 2017; 17: 379

34. Offersen BV, Boersma LJ, Kirkove C, et al. ESTRO consensus guideline on target volume delineation for elective radiation therapy of early stage breast cancer. Radiother Oncol 2015; 114: 3-10.

35. Qin T, Yuan ZY, Peng RJ, et al. Clinical research clinicopathologic characteristics and prognostic factors for HER2-positive patients with metastatic breast cancer in southern China. Arch Med Sci 2015; 11: 544-50. 